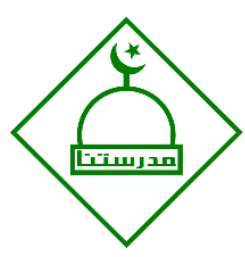

\title{
Penerapan metode SQ3R berbasis daring untuk meningkatkan keterampilan membaca pemahaman siswa
}

\author{
Yola Sofi Pandeas ${ }^{1}$, Dyah Lyesmaya ${ }^{2}$, Arsyi Rizqia Amalia ${ }^{3}$ \\ Program Studi Pendidikan Guru Sekolah Dasar, Universitas Muhammadiyah Sukabumi, Indonesia \\ Yolasofi5@gmail.com, lyesmaya_dyah@ummi.ac.id,rizqiaarsyi@gmail.com
}

\begin{abstract}
ABSTRAK
Penelitian ini bertujuan untuk mendeskripsikan pengingkatan keterampilan membaca pemahaman melalui penerapan metode SQ3R (Survey, Question, Read, Recite, Review)berbasis daring. Penelitian ini dilakukan dengan subjek penelitian kepada siswa kelas IV di salah satu SD Negeri Baros Kencana CBM di Kota Sukabumi semester II Tahun pelajaran 2019/2020 sebanyak 30 siswa, terdiri dari 15 siswa lakilaki dan 15 siswa perempuan. Metode yang digunakan adalah Penelitian Tindakan Kelas (PTK) dengan desain penelitian menggunakan model Kemmis dan Mc. Taggart yang terdiri dari tahap perencanaan, pelaksanaan, observasi, refleksi. Teknik pengumpulan data dengan menggunakan wawancara, observasi, catatan lapangan dan tes. Dari hasil penelitian pada pra siklus melalui tes indikator keterampilan membaca pemahaman siswa menunjukkan ketuntasan 23 . Kemudian meningkat pada siklus I sampai siklus II yaitu, siklus I (53\%), siklus II (87\%). Kesimpulan dari penelitian ini adalah melalui penggunaan metode SQ3R (Survey, Question, Read, Recite, Review) berbasis daring dapat meningkatkan keterampilan membaca pemahaman siswa kelas IV SD Negeri Baros Kencana CBM di Kota Sukabumi Semester II Tahun Pelajaran 2019/2020.
\end{abstract}

Kata Kunci : SQ3R, Daring, Keterampilan Membaca Pemahaman

\section{Application of online-based SQ3R method to improve students' reading comprehension skills}

\begin{abstract}
This study aims to describe the improvement of reading comprehension skills through the application of online-based SQ3R (Survey, Question, Read, Recite, Review) methods. This research was conducted with research subjects to fourth grade students in one of the Baros Kencana Public Elementary Schools in Sukabumi City in the second semester of 2019/2020 Academic Year as many as 30 students, consisting of 15 male students and 15 female students. The method used is Classroom Action Research (CAR) with a research design using the Kemmis and Mc. Taggart which consists of the stages of planning, implementation, observation, reflection. Data collection techniques using interviews, observation, and tests. From the results of the study in the pre cycle through the test indicators of reading comprehension skills of students showing completeness 23. Then increase in cycle I to cycle II, that is, cycle I (53\%), cycle II (87\%). The conclusion of this study is through the use of the online-based SQ3R (Survey, Question, Read, Recite, Review) method that can improve reading comprehension skills of Grade IV at $f$ Baros Kencana CBM Elementary school in Sukabumi City Semester II accademic year 2019/2020.
\end{abstract}

Keywords: SQ3R, Large, reading comprehension skills. 


\section{PENDAHULUAN}

Pembelajaran Bahasa Indonesia tidak difokuskan pada penguasaan komponen kebahasaan, akan tetapi harus menguasai komponen keterampilan bahasa. Keterampilan membaca merupakan salah satu keterampilan yang harus dikuasai oleh siswa sekolah dasar dalam pembelajaran Bahasa Indonesia, keterampilan membaca sangat menunjang keberhasilan siswa dalam belajar.

Membaca itu sangat penting, salah satunya membaca pemahaman yang harus ditingkatkan karena membaca pemahaman bertujuan untuk memperoleh informasi yang terkandung dalam teks bacaan (Abidin, 2012: 59). Hal yang harus diperhatikan dalam membaca adalah kemampuan seseorang dalam memahami teks bacaan secara menyeluruh, dengan demikian disebut dengan membaca pemahaman. Rendahnya kemampuan membaca dengan pemahaman ini menjadi masalah yang serius dalam mata pelajaran Bahasa Indonesia.

Berdasarkan hasil wawancara dengan wali kelas IV D yang telah dilaksanakan pada tanggal 08 November 2019 di SDN Baros Kencana CBM, permasalahan yang didapat yaitu siswa memiliki kesulitan dalam membaca pemahaman pada pembelajaran Bahasa Indonesia antara lain: 1) Siswa belum mampu memahami isi teks bacaan; 2) Siswa belum mampu menemukan kalimat utama dalam teks bacaan; 3) Siswa belum mampu menjawab pertanyaan sesuai dengan teks bacaan; 4) Siswa belum mampu menyimpulkan isi teks bacaan.

Hal ini dapat dilihat dari nilai UTS, bahwa hasil belajar siswa pada mata pelajaran Bahasa Indonesia adalah 10 (33,3\%) dari 30 siswa yang sudah mencapai KKM, sedangkan 20 (66,7\%) orang siswa tidak mencapai KKM. Rendahnya keterampilan membaca pemahaman siswa berdasarkan hasil wawancara guru menyampaikan bahwa dalam pelajaran Bahasa Indonesia atau membaca guru lebih sering menggunakan metode ceramah dan hanya memberikan teks-teks bacaan.

Berdasarkan permasalahan di atas, menunjukkan bahwa keterampilan membaca siswa masih rendah, permasalahan ini perlu ditindaklanjuti karena pembelajarannya belum sepenuhnya inovatif dan metode yang diterapkan juga belum bervariasi. Salah satu upaya yang dapat dilakukan adalah penerapan metode pembelajaran untuk meningkatkan keterampilan membaca pemahaman, untuk itu peneliti memilih menerapkan metode SQ3R berbasis daring. Karena metode ini cocok untuk keterampilan membaca pemahaman pada siswa yang menjadikan siswa aktif dalam kegiatan membaca, siswa menjadi mudah memahami isi bacaan.

Adapun penelitian yang dilakukan sebelumnya dalam menerepakan metode SQ3R sebagai pilihan yang dapat dinyatakan berhasil untuk meningkatkan hasil pembelajaran yang dapat membuat siswa lebih aktif dan antusias dalam mengikuti proses pembelajaran (Nadzifah, 2016: 2.730-2.731). 
Dari uraian di atas maka peneliti menggunakan metode SQ3R berbasis daring dengan tujuan untuk meningkatkan keterampilan membaca pemahaman. Keterampilan membaca pemahaman sangatlah penting untuk penguasaan materi pada diri siswa.

\section{METODE PENELITIAN}

Penelitian ini merupakan penelitian tindakan kelas (PTK). Menurut Kunandar (2012: 41) "penelitian tindakan kelas (PTK) merupakan peranan yang sangat penting dan strategis untuk meningkatkan mutu pembelajaran apabila diimplementasikan dengan baik dan benar". Penelitian tindakan kelas (PTK) menurut Aqib, Jaiyaroh, Diniati, \& Khotimah (2014: 3) adalah "penelitian yang dilakukan oleh guru di kelasnya sendiri melalui refleksi diri dengan tujuan untuk memperbaiki kinerjanya sehingga hasil belajar siswa meningkat".

Partisipan tempat dalam penelitian ini adalah siswa kelas IV D SDN Baros Kencana CBM Kota Sukabumi sebanyak 30 siswa, peneliti 1 orang dan guru kelas 1 orang. Sedangkan subjek dalam peneltian ini adalah keterampilan membaca pemahaman siswa kelas IV D. Peran peneliti dalam penelitian ini adalah memberikan tindakan, penganalisis data, dan pelapor sebagai hasil tindakan penelitian.

Penelitian ini dilaksanakan secara daring melalui grup whatsapp di kelas IV SDN Baros Kencana CBM Kota Sukabumi, yang beralamat di Jalan Garuda No.10 Kecamatan Baros, Kelurahan Baros Kota Sukabumi. Waktu penelitian dilaksanakan pada semester genap tahun ajaran 2019/2020.

Tahap Perencanaan Penelitian menentukan KI dan KD yang cocok dengan permasalahan yang diangkat tentang membaca pemahaman.Menyusun Rencana Pelaksanaan Pembelajaran (RPP) Daring dengan menggunakan metode SQ3R (Survey, Question, Read, Recite, dan Review). Membuat teks bacaan. Menyiapkan daftar hadir siswa. Menyusun instrumen penelitian sebagai pengumpulan data berupa lembar observasi guru dan siswa. Membuat lembar kerja siswa untuk mengetahui peningkatan keterampilan membaca pemahaman siswa. Konsultasi RPP dan instrumen dengan dosen pembimbing.

Berdasarkan uraian di atas pada tahap perencanaan tindakan peneliti menyusun tahap-tahap penelitian, dari mulai menentukan KI dan KD sampai mempersiapkan media pembelajaran untuk proses pembelajaran yang akan dilaksanakan. Tahap Pelaksanaan Tindakan

Tahap pelaksanaan tindakan, peneliti melaksanakan pembelajaran sesuai dengan sintkas metode pembelajaran SQ3R (Survey, Question, Read, Recite, Review) yang telah dikembangkan dalam RPP. Adapun langkah-langkah melalui penerapan metode pembelajaran SQ3R pada siklus I adalah sebagai berikut:

\section{Survey}

Pada tahap ini guru memberikan teks bacaan kepada siswa, lalu siswa membaca sekilas tentang bacaan tersebut. 


\section{Question}

Pada tahap ini guru menyuruh siswa untuk membuat pertanyaan mengenai teks bacaan itu berdasarkan $5 \mathrm{~W}+1 \mathrm{H}$ (apa, kapan, dimana, siapa, mengapa dan bagaimana)

Read

Pada tahap ini guru menyuruh siswa untuk membaca keseluruhan teks bacaan tersebut.

\section{Recite}

Pada tahap ini siswa menceritakan kembali berdasarkan pertanyaan.

\section{Review}

Pada tahap ini siswa meninjau kembali bahan bacaan dan membandingkan jawabannya dengan teks bacaan.

Pengumpulan Data

\section{Wawancara}

Menurut Kunandar (2012: 157) "wawancara digunakan untuk mengungkap data yang berkaitan dengan sikap, pendapat, atau wawasan. Wawancara merupakan pertanyaan pertanyaan yang diajukan secara verbal kepada orang-orang yang dianggap dapat memberikan informasi atau penjelasan hal-hal yang dipandang perlu dan memiliki relevansi dengan permasalahan penelitian tindakan kelas”. Wawancara dilakukan pada saat pendahuluan kepada wali kelas IV D mengenai permasalahan yang ada dikelas dan mengenai model pembelajaran yang sudah bervariasi atau belum.

Observasi

Menurut Sanjaya (2011: 86) “observasi merupakan teknik mengumpulkan data dengan cara mengamati setiap kejadian yang sedang berlangsung dan mencatatnya dengan alat observasi tentang halhal yang akan diamati dan diteliti”. Observasi dilakukan untuk mengukur sejauh mana kinerja guru dan kinerja siswa dengan menggunakan metode SQ3R berbasis daring yang dilaksanakan oleh peneliti, yang menjadi observernya adalah guru kelas dan observer yang dilakukan kepada siswa yang menjadi observernya adalah orang tua siswa.

Tes

Tes adalah serentetan pertanyaan atau latihan serta alat lain yang digunakan untuk mengukur keterampilan, pengetahuan intelegensi, kemampuan atau bakat yang dimiliki oleh individu atau kelompok Arikunto (2013 :193)". Tes yang digunakan adalah tes untuk mengukur pengetahuan siswa dalam kegiatan pembelajaran. 
Instrumen tes ini digunakan untuk megukur kemampuan membaca pemahaman siswa setelah menggunakan metode SQ3R dalam proses pembelajaran. Tes ini menggunakan tes tulis yang sesuai dengan indikator dan instrument penilaian terdapat di lampiran.

Pengolahan Data

Wawancara melakukan wawancara dengan guru untuk mengetahui permasalahan. Menganalis hasil wawancara. Menyajikan hasil wawancara.

Observasi

Aktivitas Guru, Guru mendapatkan sekor hasil observasi dari obsever. Menghitung hasil skor yang diperoleh. Dengan menggunakan rumus sebagai berikut:

\section{Aktifitas Siswa}

$$
\text { Nilai }=\frac{\text { jumlah skor yang diperoleh }}{\text { jumlah skor maksimal }} \mathrm{X}
$$

1 nnח1

Kinerja guru yang dilakukan dari awal hingga akhir pembelajaran, dapat diperoleh dengan menggunak rumus sebagai berikut :

$$
\text { Nilai }=\frac{\text { jumlah } \text { skor } \text { yang diperoleh }}{\text { jumlah skor maksimal }} \mathrm{X}
$$

(Sumber Hamzah, 2014:279)

\section{HASIL PENELITIAN DAN PEMBAHASAN}

Pelaksanaan siklus I selama 2 kali pertemuan yang dilaksanakan pada hari senin 8 Juni dan Jumat 12 Juni 2020. Pelaksanaan tindakan diamati oleh observer yang terdiri dari 1 orang teman sejawat mengamati aktivitas guru, dan untuk observer siswa adalah orangtua siswa yang mengamati aktivitas siswa, serta melakukan dokumentasi selama proses pembelajaran. Pelaksanaan tindakan siklus I terdiri dari empat tahapan yaitu perencanaan, pelaksanaan \& observer, dan refleksi.

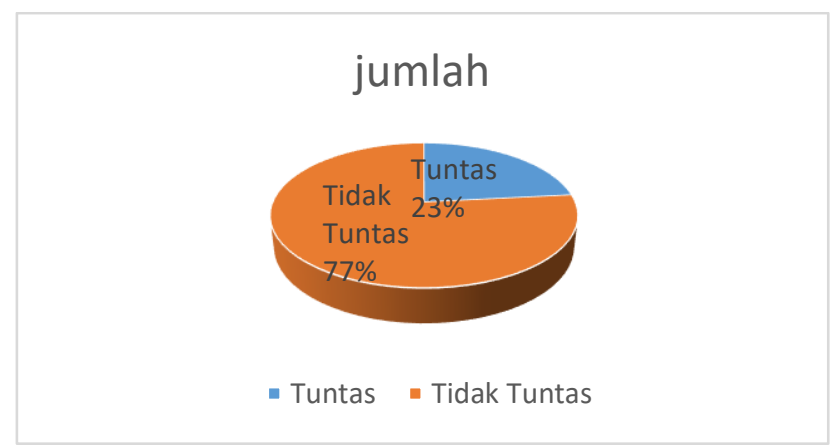

Gambar 4.1 Diagram Ketuntasan Membaca Pemahaman Pra Siklus 
Berdasarkan gambar 4.1 hasil ketuntasan membaca pemahaman pada pra siklus bahwa hanya 7 $(23,33 \%)$ orang siswa yang tuntas. Hal ini dikarenakan permasalahan yang dialami adalah rendahnya keterampilan membaca pemahaman siswa kelas IVD SD Negeri Baros Kencana CBM. Pencapaian pada penelitian ini dapat dilihat dari temuan pada setiap indikator keterampilan membaca pemahaman pada siklus I. Adapun hasil tes membaca pemahaman dapat dilihat pada diagram perbandingan setiap indikator yang tersaji pada gambar 4.2 sebagi berikut.

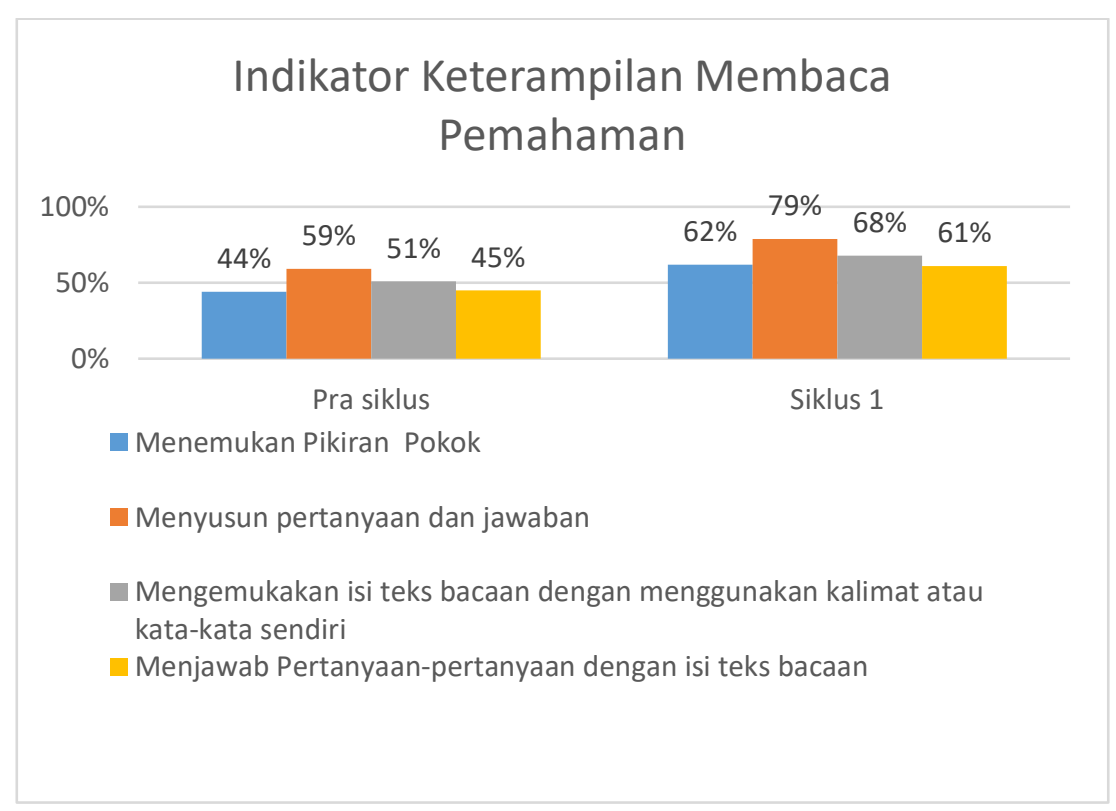

Gambar 4.2 Diagram Perbandingan Pra Siklus dan Siklus I Keterampilan Membaca

\section{Pemahaman}

Berdasarkan pada gambar 4.2 maka dapat dilihat ketercapaian dari setiap indikator keterampilan membaca pemahaman siswa pada siklus I sudah menunjukkan peningkatan dari hasil sebelumnya

Adapun deskripsi dari setiap indikator adalah sebagai berikut.

Menemukan pikiran pokok

Pada indikator ini siswa sudah mampu menentukan kalimat utama, dibuktikan pada saat guru memberikan pertanyaan kepada siswa mengenai kalimat utama, selain itu dilihat pada saat guru memberikan lembar evaluasi kepada siswa ada beberapa siswa yang sudah mampu menentukan kalimat utama.

Menyusun pertanyaan dan jawaban

Siswa sudah mampu menyusun pertanyaan berdasarkan unsur 5W1H dan jawaban berdasarkan teks bacaan, dibuktikan pada saat siswa diminta untuk menyusun pertanyaan berdasarkan teks bacaan beberapa siswa sudah mampu membuat 2 pertanyaan dari 6 unsur yang telah ditentukan. Namun masih ada siswa yang belum mampu menyusun pertanyaan menggunakan unsur 5W1H. 
Mengemukakan isi teks bacaan dengan menggunakan kalimat atau kata-kata sendiri

Siswa sudah mampu mengemukakan isi teks bacaan dengan kalimat sendiri menggunakan EYD yang baik dan benar sesuai kaidah Bahasa Indonesia, dilihat dari hasil tes membaca pemahaman ada beberapa siswa sudah mampu menyimpulkan isi teks bacaan.

Menjawab pertanyaan berdasarkan teks yang diberikan.

Pada indikator ini seluruh siswa sudah mampu menjawab pertanyaan berdasarkan teks bacaan atau sesuai dengan apa yang terdapat pada teks bacaan. Dilihat dari hasil teks membaca pemahaman siswa sudah mampu mengisi semua pertanyaan yang berkaitan dengan teks bacaan.

Berdasarkan keterlaksanaan siklus I pada pembelajaran Bahasa Indonesia dapat memberikan dampak baik terhadap peningkatan disetiap indikator keterampilan membaca pemahaman. Adapun ketuntasan pada siklus I dapat diliha pada gambar 4.3 Sebagai berikut.

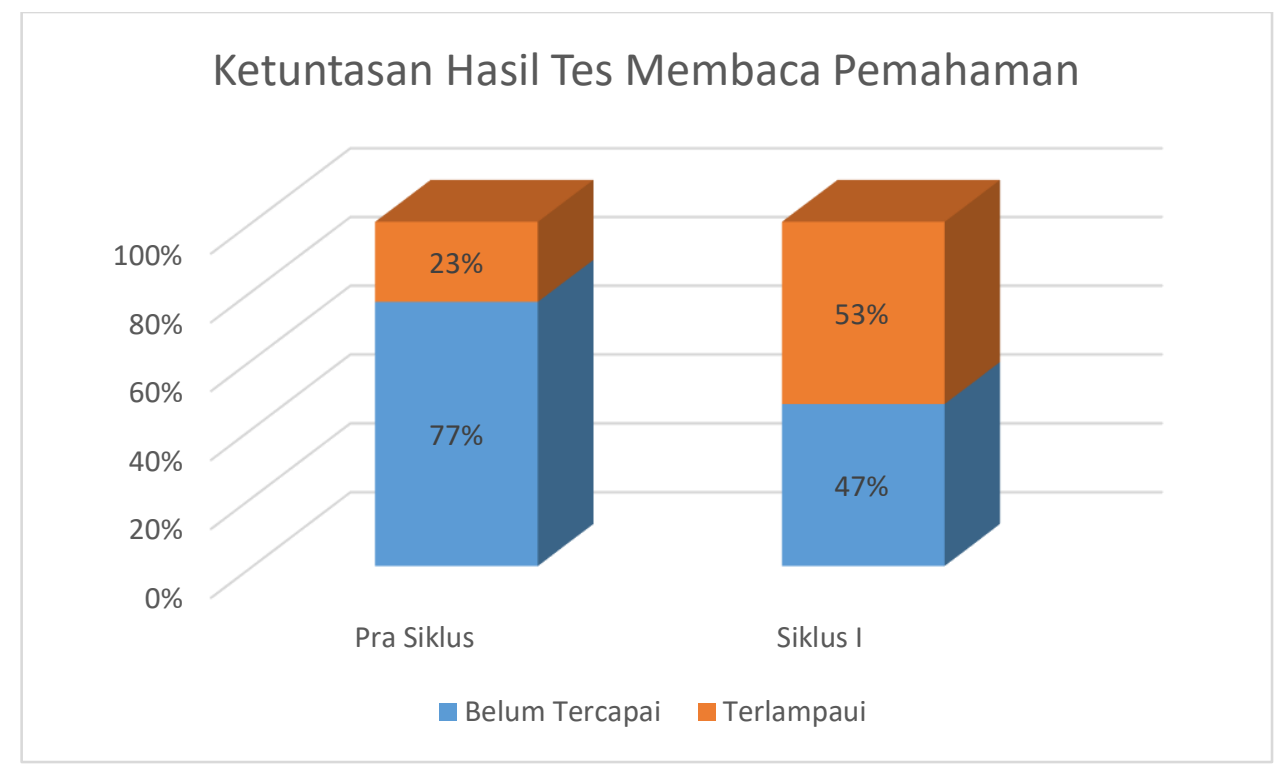

\section{Gambar 4.3 diagram ketuntasan hasil test membaca pemahaman}

Berdasarkan data di atas menunjukkan peningkatan dari pra siklus ke siklus I sebesar 30\%. Peningkatan siswa dalam keterampilan membaca pemahaman meningkat setelah dilakukannya tindakan siklus I. Sebanyak 7 orang siswa yang mengalami peningkatan dari hasil pra siklus, meskipun peningkatan pada siklus I belum maksimal dan belum mencapai indikator keberhasilan yang telah ditentukan. Maka perlu diadakan perbaikan pada siklus selanjutnya untuk hasil yang lebih maksimal.

Pencapaian pada penelitian ini data dilihat dari temuan pada setiap indikator keterampilan membaca pemahaman pada siklus II. Adapun hasil tes membaca pemahaman dapat dilihat pada diagram perbandingan setiap indikator yang tersaji pada gambar 4.4 Sebagai berikut. 


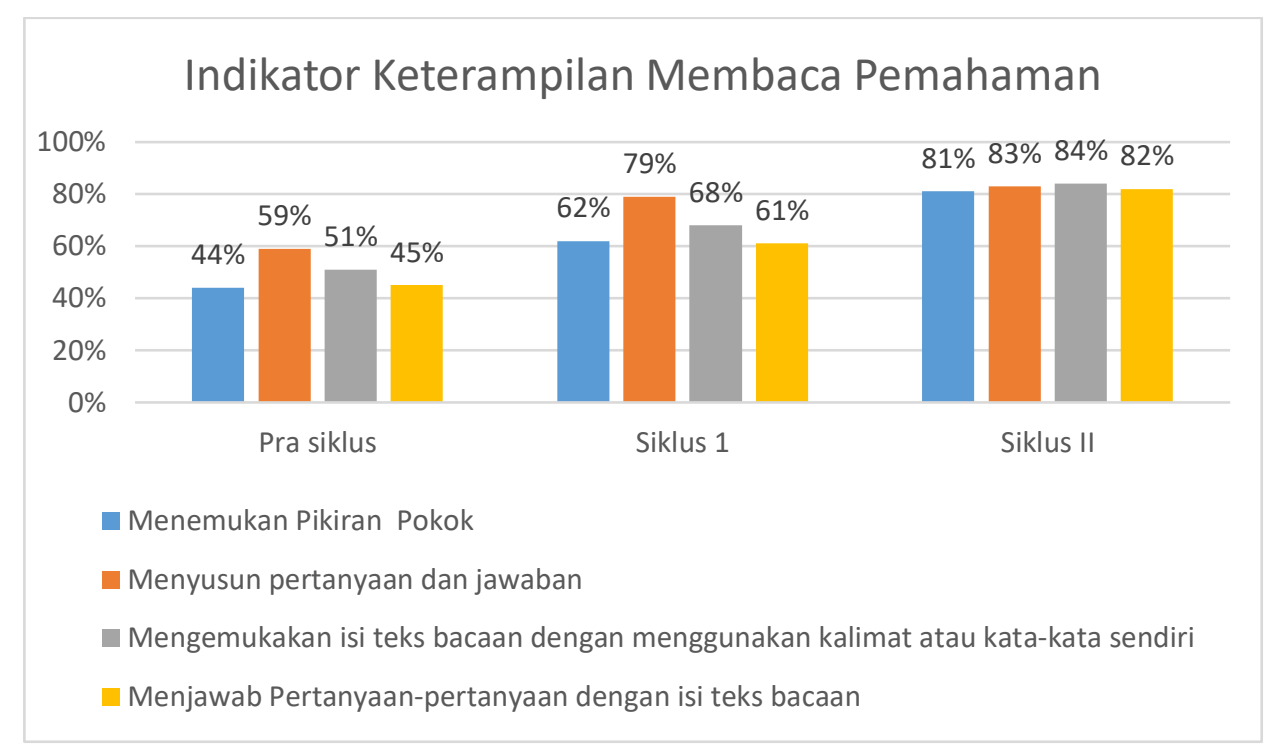

Berdasarkan data gambar 4.4 Maka dapat dilihat ketercapaian dari setiap indikator keterampilan membaca pemahaman siswa pada siklus II sudah menunjukkan peningkatan dari hasil sebelumnya.

Berdasarkan peningkatan keterampilan membaca pemahaman dari setiap indikator telah dijelaskan di siklus II memperoleh nilai peningkatan yang berbedaan, pada siklus II siswa diberikan perlakuan dan tindakan yang sama. Hal ini karena siswa belum terbiasa untuk membaca dan membiasakannya, sehingga terbawa sampai pembelajaran. Seharusnya untuk melatih keterampilan membaca pemahaman siswa, siswa harus dibiasakan untuk membaca dan memahami apa yang telah dibacanya.

Ketercapaian siklus II keterampilan membaca pemahaman pada mata pelajaran Bahasa Indonesia mengalami peningkatan yang signifikan dibandingkan pra siklus dan siklus I. Berikut diagram ketuntasan keterampilan membaca pemahaman disajikan pada gambar 4.5 Sebagai berikut.

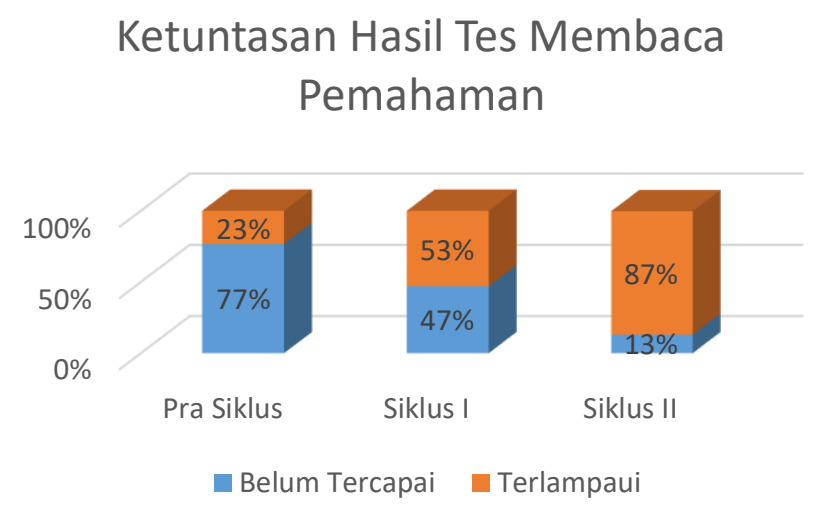

Gambar 4.5 Diagram Ketuntasan Test Membaca Pemahaman 
Berdasarkan data di atas menunjukkan peningkatan dari pra siklus ke siklus I sebesar $30 \%$, peningkatan siswa dalam keterampilan membaca pemahaman meningkat setelah dilakukannya tindakan siklus I. Sebanyak 16 orang siswa mengalami peningkatan dari hasil pra siklus, pada siklus II siswa mengalami peningkatan yang signifikan sebesar 33,34 \% dari siklus sebelumnya. Hal ini karena pada siklus II guru memberikan tindakan secara maksimal dan siswa sudah terbiasa dengan metode yang diterapkan oleh guru, dalam satu siklus terdapat dua pertemuan, setiap pertemuan siswa diberikan tes membaca pemahaman, pada siklus II pertemuan I (10 orang) siswa (66,67\%) yang tuntas mencapai KKM, sedangkan pada pertemuan 2 (26 orang) siswa (88,67\%) mencapai KKM, sehingga data pada diagram ketuntasan mengalami kenaikan secara signifikan.

Terbukti dari peningkatan pra siklus, siklus I dan siklus II. Maka penerapan metode SQ3R dapat meningkatkan keterampilan membaca pemahaman. Siklus pada penelitian ini dihentikan karena telah mencapai indikator keberhasilan yang telah ditentukan yaitu, siklus dihentikan apabila ketuntasan siswa mencapai $80 \%$ secara klasikal.

\section{SIMPULAN}

Berdasarkan hasil temuan dan pembahasan, dapat disimpulkan bahwa keterampilan membaca pemahaman siswa kelas IVD SD Negeri Baros Kencana CBM Kota Sukabumi meningkat dengan menggunakan metode SQ3R berbasis daring. Peningkatakan keterampilan membaca pemahaman siswa kelas IVD SD Negeri Baros Kencana CBM Kota Sukabumi ditunjukkan dengan adanya peningkatan kualitas proses pembelajaran dan peningkatan hasil pembelajaran. Peningkatakan proses pembelajaran ditunjukkan dengan siswa lebih aktif dan antusias mengikuti proses pembelajaran menggunakan metode SQ3R berbasis daring.

\section{Pelaksanaan Metode SQ3R Berbasis Daring}

Pelaksanaan keterampilan membaca pemahaman pada mata pelajaran Bahasa Indonesia pada siswa kelas IV SD Negeri Baros Kencana CBM dengan menggunakan metode SQ3R berbasis daring pada penelitian ini adalah sebagai berikut. Tahap pertama yang dilakukan adalah tahap Survey, Question, Read, Recite, dan Review. Berdasarkan hasil observasi aktivitas guru yang memperoleh nilai rata-rata 69 siklus I dengan kategori cukup. Sedangkan nilai rata-rata pada siklus 2 memperoleh nilai 89 dengan kategori sangat baik. Aktivitas pembelajaran memperoleh nilai rata-rata 72 siklus I dengan kategori cukup. Sedangkan hasil nilai rata-rata pada siklus 2 adalah 87 dengan kategori sangat baik.

Peningkatan Keterampilan Membaca Pemahaman 
Peningkatan hasil pembelajaran keterampilan membaca pemahaman siswa kelas IVD Negeri Baros Kencana CBM Kota Sukabumi adalah sebagai berikut. Presentase hasil tes membaca pemahaman siswa yang mencapai indikator yang ditentukan atau presentase siswa yang mencapai nilai 80 pada pra siklus mencapai 23,33 \% (7 orang siswa yang tuntas), pada siklus I mencapai 53,33\% (16 orang siswa tuntas), dan pada siklus II mencapai 86,67 \% (26 orang siswa tuntas). Hasil tersebut menunjukkan bahwa pembelajaran keterampilan membaca pemahaman menggunakan metode SQ3R berbasis daring telah memenuhi indikator keberhasilan dalam penelitian ini. Sehingga penelitian ini dapat dikatakan berhasil.

\section{DAFTAR PUSTAKA}

Abidin, Y. (2012). Pembelajaran Membaca Berbasis Pendidikan Karakter. Bandung: PT Refika Aditama.

Arikunto. (2014). Penelitian Tindakan Kelas. Jakarta: PT Bumi Aksara.

Aqib, Z., Jaiyaroh, S., Diniati, E., \& Khotimah, K. (2014). Penelitian Tindakan Kelas. Bandung: CV. YRAMA WIDYA.

Hamzah, Ali. (2014). Evaluasi Pembelajaran Matematika. Jakarta : PT Raja Grafindo Persada

Kunandar. (2012). Penelitian Tindakan Kelas. Jakarta : PT Raja Grapindo Persada.

Nadzifah, W. (2016). Meningkatkan Keterampilan Membaca Pemahaman Menggunakan Metode Sq3R Siswa Kelas Iv Sd N Katongan I Improving the Reading Comprehension Skill Using Sq3R Method in Fourth. Jurnal Pendidikan Guru Sekolah Dasar, 5(28), 2721-2731.

Sanjaya, wina. (2011). Penelitian Tindakan Kelas. Jakarta: Prenada Media Group. 